\title{
Seed disinfestation methods for in vitro cultivation of epiphyte orchids from Southern Brazil ${ }^{1}$
}

\author{
Veronica M Alvarez-Pardo5; Alfredo Gui Ferreira ${ }^{2 ; 3}$; Valter F Nunes ${ }^{4}$ \\ ${ }^{2}$ Department of Botany, UFRGS, Av. Bento Gonçalves 9500, Campus do Vale, prédio 43423, 91501-970 Porto Alegre-RS, Brasil; E-mail: \\ ferreira@unb.br (corresponding author); ${ }^{3} \mathrm{CNPq}$ scholarship; ${ }^{4} \mathrm{Technician}$ from the Department of Horticulture, UFRGS; ${ }^{5} \mathrm{CAPES}$ \\ scholarship
}

\begin{abstract}
Disinfestation of orchid seeds is necessary when the germination is performed in vitro. In such case, cultures are supplemented by a source of sugar and salts in order to obtain energy and other requirements. However, the presence of sugar and salts easily allows the development of unwanted microorganisms. To avoid such phenomenon, an efficient procedure must be done as a pretreatment of the seeds with liquid or gaseous substances. In this study with several Brazilian orchids, the seeds were disinfested with sodium hypochlorite solutions containing $0.4 \%$ or $0.8 \%$ active chlorine for five minutes and sodium hypochlorite or formaldehyde fumes up to two hours, this procedure being efficient for such purpose and making it possible to be used routinely.
\end{abstract}

Keywords: orchids, in vitro culture, germination, sodium hypoclorite, formaldehyde.

\begin{abstract}
RESUMO
Métodos de desinfestação de sementes para o cultivo in vitro de orquídeas epífitas do Sul do Brasil

A desinfestação de sementes de orquídeas é necessária quando a germinação é efetuada in vitro. Neste caso, as culturas são suplementadas por uma fonte de açúcar e de sais, para prover energia e outras necessidades. A presença de açúcares e sais facilmente permite o desenvolvimento de microorganismos indesejáveis. Para evitar estes microorganismos, um procedimento eficiente deve ser usado como pré-tratamento das sementes com substâncias liquidas ou gasosas. Neste ensaio com várias espécies de orquídeas brasileiras, as sementes foram desinfestadas com solução de hipoclorito de sódio $0,4 \%$ ou $0,8 \%$ de cloro nascente por cinco minutos ou, por vapores de formol ou hipoclorito de sódio por até duas horas, sendo eficientes estes procedimentos para desinfestação e possível seu uso rotineiramente.
\end{abstract}

Palavras-chave: orquídeas, cultivo in vitro, germinação, hipoclorito de sódio, formaldeido.

\section{(Recebido para publicação em 18 de março de 2005; aceito em 2 de maio de 2006)}

E piphyte orchids have been multiplied routinely from seeds, using a non-symbiotic culture as a propagation method (Knudson, 1922). The inoculation in vitro is the main technique for micro-propagation without symbiotic mycorrhizae association. In order to properly develop this technique, sugar and salts are required in a sterile culture medium, where seeds are free from microorganisms.

Orchid embryos can be cultivated in vitro, using immature seeds (Kerbauy \& Handro, 1981). In such case, the seeds are taken from the closed capsule to prevent contamination when no other inhibition of germination is found (Van der Kinderen, 1987; Rasmussen et al., 1990). This procedure is not suitable for a germplasm bank, because seeds must reach maturity and have low water content to be stored (Pritchard \& Seaton, 1993). For germination, the disinfestation is mandatory before inoculation.

The disinfestant liquid should remove or kill all microorganisms from the seeds' surface without damaging the embryos. For the purpose of disinfesting orchid seeds, calcium hypochlorite is the most used one (Wilson, 1915; Thompson, 1980; Arditti et al., 1982), besides hydrogen peroxide (Snow, 1985) and sodium hypochlorite (Pierik, 1990). Calcium hypochlorite needs to be filtered before utilization, and cannot be stored over 12 hours (Arditti et al., 1982). Sodium hypochlorite also needs to be fresh, since both are alkaline and lose chloride, the active oxidizing ion, which captures oxygen, killing the aerobic microorganisms and fungi spores, which in turn, are mainly responsible for most of the contamination. These chemicals can improve somehow the germination in a few species by light scarification of the seeds (Haas-von Schmude et al., 1986; Van Waes \& Debergh, 1986).

Sodium and calcium hypochlorite are prescribed to be used at different concentrations and times of exposure to disinfest seeds (Singh, 1988; Butcher \& Marlow, 1989; Seaton \& Hailes, 1989; Oddie et al., 1994; Chu \& Mudge, 1994). In spite of it, some contamination may appear due to small cracks on the surface of seeds that may keep a few spores. Applying sodium hypochlorite fumes for 5 to 30 minutes can solve this problem, allowing a complete disinfestation (Arditti \& Ernst, 1992).

In the attempt to attain an efficient method for several Brazilian epiphyte

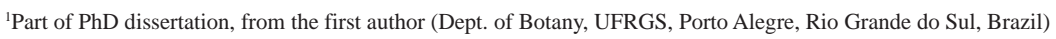


Table 1. Initial viability and orchid seeds germination percentage, disinfested with two sodium hypoclorite concentrations with $0.4 \%$ or $0.8 \%$ of active chloride for $5 ; 15 ; 30$ and 60 minutes periods. Porto Alegre, UFRGS, 2004.

\begin{tabular}{|c|c|c|c|c|c|c|c|c|c|}
\hline \multirow{4}{*}{ Species } & \multirow{4}{*}{$\begin{array}{c}\text { Viability } \\
(\%)\end{array}$} & \multicolumn{8}{|c|}{ Seed germination (\%) } \\
\hline & & \multicolumn{4}{|c|}{$0.4 \% \mathrm{NaCl}$} & \multicolumn{4}{|c|}{$0.8 \% \mathrm{NaCl}$} \\
\hline & & \multicolumn{8}{|c|}{ Time in minutes* } \\
\hline & & 05 & 15 & 30 & 60 & 05 & 15 & 30 & 60 \\
\hline Bifrenaria inodora & $84 \pm 2$ & $79 a$ & $47 b$ & $24 c$ & 03d & $77 a$ & $52 b$ & Oc & $\mathrm{Oc}$ \\
\hline Brassavola tuberculata & $97 \pm 2$ & $98 a$ & $97 a$ & $90 a$ & $06 \mathrm{~d}$ & $91 a$ & $34 b$ & $30 \mathrm{c}$ & 02 \\
\hline Cattle ya bicolor & $99 \pm 1$ & $97 a$ & $89 b$ & $58 c$ & $10 \mathrm{~d}$ & $97 a$ & $63 c$ & $0 \mathrm{e}$ & Oe \\
\hline C. intermedia & $99 \pm 1$ & $100 \mathrm{a}$ & $97 a$ & $95 a$ & $03 c$ & $99 a$ & $56 b$ & Oc & $\mathrm{Oc}$ \\
\hline C. intermedia pallida & $99 \pm 1$ & $100 \mathrm{a}$ & $99 a$ & $95 a$ & $06 d$ & $100 \mathrm{a}$ & $27 b$ & $11 \mathrm{c}$ & Oe \\
\hline Encyclia pygmaea & $99 \pm 1$ & $88 a$ & $60 b$ & $0 c$ & $0 c$ & $90 a$ & $53 b$ & $0 \mathrm{c}$ & $0 c$ \\
\hline Epidendrum fulgens & $86 \pm 3$ & $74 a$ & $53 b$ & $04 c$ & Od & $52 b$ & $02 c$ & $0 d$ & $\mathrm{Od}$ \\
\hline Laelia purpurata & $96 \pm 2$ & $94 a$ & $77 b$ & $34 d$ & Oe & $88 b$ & $71 \mathrm{c}$ & $05 e$ & $\mathrm{Oe}$ \\
\hline Miltonia regnellii & $88 \pm 2$ & $81 a$ & $76 b$ & $22 d$ & Oe & $75 b$ & $38 \mathrm{c}$ & $01 \mathrm{e}$ & $\mathrm{Oe}$ \\
\hline Oncidium pumilum & $98 \pm 3$ & $98 a$ & $69 b$ & $02 c$ & $0 c$ & $75 b$ & $0 \mathrm{c}$ & $0 \mathrm{c}$ & $0 \mathrm{c}$ \\
\hline Pleurothallis glumacea & $74 \pm 2$ & $60 \mathrm{a}$ & $26 b$ & $11 d$ & Of & $18 \mathrm{c}$ & $04 \mathrm{e}$ & of & Of \\
\hline
\end{tabular}

*Different letters indicate statistical differences among treatments. Tukey test, $\mathrm{p}<0.05$.

orchid seeds inoculation, four procedures were devised: two with liquid $(0.4 \%$ and $0.8 \%$ of active chloride), and two with gaseous substances (5.5\% sodium hypochlorite and $99 \%$ formaldehyde fumes).

\section{MATERIAL AND METHODS}

Bifrenaria inodora Lindl., Brassavola tuberculata Hook., Cattleya bicolor Lindl., C. intermedia R.Grah, $C$. intermedia var. pallida Lindl., Encyclia pygmeae (Hook.) Dressler, Epidendrum fulgens A.Brongn., Laelia purpurata Lindl. \& Paxt, Miltonia regnelli Reichb., Oncidium pumicum Lindl., Pleurothallis glumacea Lindl. were collected from native stands in the Northern and Eastern regions of the Rio Grande do Sul State, Brazil, in 1999 and 2000. Ripe capsules were dehydrated (Seaton \& Prichard, 1989) and stored at $5^{\circ} \mathrm{C} \pm 1{ }^{\circ} \mathrm{C}$, in the laboratory of the Federal University of Rio Grande do Sul. The disinfestation was carried out in two ways, by a moisten bath and gaseous exposition.

Moisten bath: Twenty milligrams of seeds from each of the eleven species were packed in 10 centimeters of plastic net ( $60 \mu \mathrm{m}$ mesh) closed by plastic clips. On a laminar flowhood using a beaker, the material was dipped in $15 \mathrm{ml}$ of Sodium hypochlorite $0.4 \%$ or $0.8 \%$ of active chlorine for $5 ; 15 ; 30$ and 60 minutes. The vials were sealed to avoid the loss of chlorine. After that, the samples were washed three times with distilled water and placed on a paper filter to dry off the excess water. The seed viability was evaluated by germination on Knudson C (Knudson, 1946) plus micronutrients (Arditi et al., 1982) and $0.05 \mathrm{mg} / \mathrm{L}$ of thiamin and nicotinic acid, $20 \mathrm{~g} / \mathrm{L}$ of sucrose and 6 $\mathrm{g} / \mathrm{L}$ of agar. The $\mathrm{pH}$ was adjusted to 5.7 with $\mathrm{NaOH}$ (Milanese, 1997). Ten milliliters of medium were autoclaved for 20 minutes at $120^{\circ} \mathrm{C}$ in glass tubes. The tubes were tilted; thus, when the medium cooled down a larger surface was formed, where the seeds were sown. The tubes were covered with plastic film and placed at $25^{\circ} \mathrm{C} \pm 2{ }^{\circ} \mathrm{C}$ in a growth room lit for 16 hours $\left(30 \mu \mathrm{mols}^{-1} \mathrm{~m}^{-2}\right)$. The swollen seeds with green embryos were observed through a stereomicroscope after 30 days of incubation and were considered as germinated (Hailes \& Seaton, 1989). A randomized design was used and the data for analysis were transformed in $\operatorname{arcsen}(\mathrm{x}+10)^{1 / 2}$ before submitted to ANOVA, and followed by Tukey test $(p<0.05)$.

Gaseous disinfestation: Twenty milligrams of Cattleya intermedia seeds were placed on a small piece $(2 \times 2 \mathrm{~cm})$ of aluminum foil on a nine-centimeter diameter Petri dish. Two milliliters of sodium hypochlorite solution $(5.5 \%$ of active chlorine) in a small vial or one tablet of formaldehyde (RioquímicaBrasil) were utilized as disinfestant. The Petri dishes were sealed with parafilm and the disinfestant was applied ranging from 30 minutes to six hours in each of them every half hour. The seed viability was evaluated as done in the first assay, by germination in Knudson $\mathrm{C}$ or by tetrazolium test. For these tests, the seeds were water embedded for 24 hours and then placed in $1 \%$ tetrazolium solution (2,3,5-triphenyl tetrazolium chloride) for 24 hours at $30^{\circ} \mathrm{C}$ (Singh, 1981). The seeds were counted through a stereomicroscope, the red ones being viable. Randomized design was used, and the coefficient of correlation was calculated from the data, then the regression curve with best adjustment was determined.

\section{RESULTS AND DISCUSSION}

The eleven species examined showed over $75 \%$ of initial viability (Table 1). The disinfestation, with increased concentration of sodium hypochlorite solution, decreased the germination, and is related to the exposure time (Table 1). The species $B$. tuberculata, $C$. intermedia and $C$. intermedia pallida were the most tolerant to the effects of the disinfestant. This may be related to the size of the seeds, the structure and ornamentation of the seed's wall (Milanese, 1997). Overall, the most effective treatment was the five-minute with $0.4 \%$ sodium hypochlorite solution (Figure 1), which reached an average of $87 \%$ germination. At this concentration and time, the treatment was effective to avoid contamination in most of the cases. The use of a small package made disinfestation more efficient, therefore for larger quantities of seeds several packages should be used.

Several protocols for orchid seed disinfestation (Thompson, 1980; Arditti et al., 1982; Snow, 1987; Pierik, 1990) were carried out using a sodium hypochlorite solution, which is simpler and less expensive (Butcher \& Marlow, 1989; Seaton \& Hailes, 1989; Chu \& Mudge, 1994: Vujanonic et al., 2000). Fresh solution and good reliable 
chemicals are required, followed by several rinsing with sterile water. These procedures are time consuming, mainly when a large quantity of seeds should be processed.

The utilization of gaseous disinfestation devised in this paper showed good results. The disinfestation period was not as restricted as that of sodium hypochlorite, and besides less manipulation was required. Thirty minutes to four hours can be used without the loss of viability (Figure. $2 \mathrm{~A})$. The tetrazolium test used as a fast viability test could show a decrease of viability after 3 hours in the presence of formaldehyde fumes, probably by acidification of seed surface (Figure 2B). The use of buffered tetrazolium solution should overcome this trouble. After one hour of treatment, no further contamination was observed. This method is recommended because of its efficacy and ease. Formaldehyde fumes can be applied also when a vial with several explants shows a localized contamination. For rare orchid materials, the recovery of in vitro contaminated explants or plantlets can be very suitable.

\section{ACKNOWLEDGEMENTS}

We thank Dr. R.A. Mendes, Dr E.T.H. Franco and Dr. MEA. Aquila for their useful suggestions to the draft; CAPES for the scholarship award given to V.M. Alvarez-Pardo, and CNPq for the productivity award given to A.G. Ferreira. To Miss Adriane F. Veras for text corrections. This work was, in part, supported by a grant from FAPERGS.

\section{REFERENCES}

ARDITTI J; CLEMENTS G; FAST G; HADLEY G; NISHIMURA G; ERNST R. 1982. Orchid seed germination and seedling culture - A manual. In: Arditti J. (Ed). Orchid biology: Reviews and perspectives II. New York: Cornell University Press. p. 244-370.

ARDITTI J; ERNST R. 1992. Micropropagation of Orchids, New York: Wiley-Interscience Publication. 682p.

BUTCHER D; MARLOW SA. 1989. Asymbiotic germination of epiphytic and terrestrial orchids. In: Pritchard HW. (Ed). Modern Methods in orchid conservation: the role of physiology, ecology and management. Cambridge: University Press. p. 31-38.

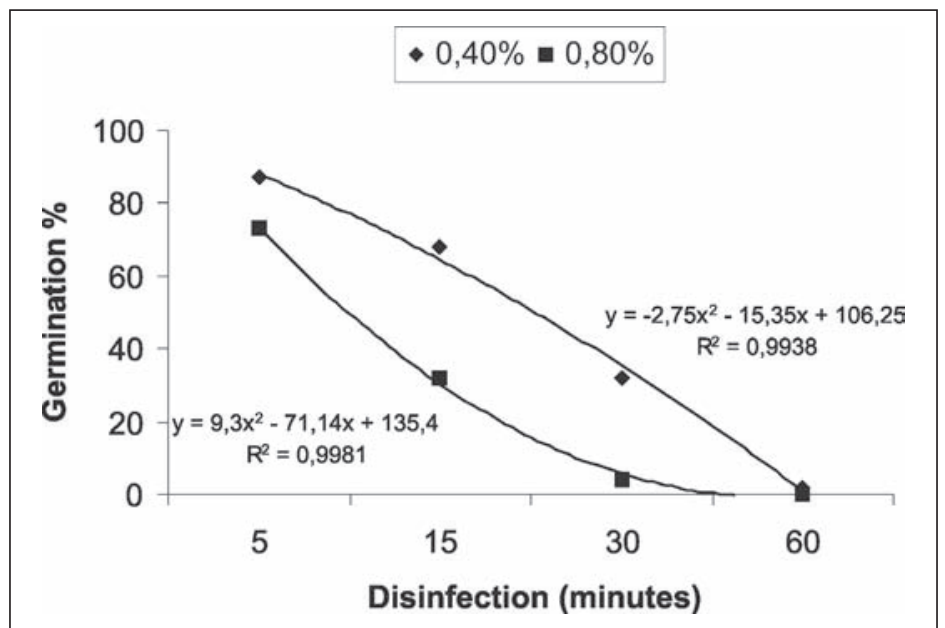

Figure 1. Germination percentage of eleven orchid species compared through polynomial regression. Disinfestation with solution in two concentrations of sodium hypochlorite with $0.4 \%$ and $0.8 \%$ of active chloride for 5; 15; 30 and 60 minutes periods. Porto Alegre, UFRGS, 2004.

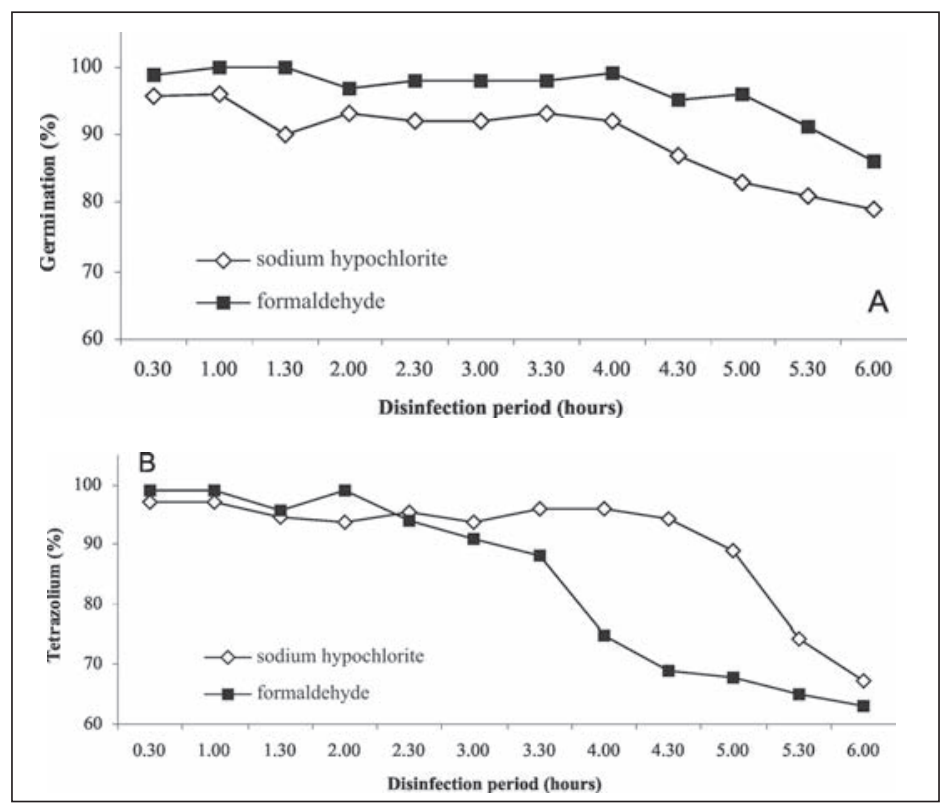

Figure 2. Germination curves (3A) and viability curves according to the tetrazolium test (3B) of Cattleya intermedia (Orchidaceae) seeds after several periods of disinfestation with formaldehyde (99\%) and sodium hypochlorite (5.5\%) fumes. Porto Alegre, UFRGS, 2004.

CHU C; MUDGE KW. 1994. Effects of pre-chilling and liquid suspension culture on seed germination of the yellow Lady's slippers orchid (Cypripedium calceolus varpuvescens). Lindleyana 9: 153-159.

HAAS-VON SCHMUDE NF; LUCKE E; ERNST R; ARDITTI J. 1986. Paphiopedilum rothschildianum. American Orchid Society Bulletin 55: 579 -584.
HAILES NSJ; SEATON PT. 1989. The effects of composition of the atmosphere on the growth of seedlings of Cattleya aurantica. In: Pritchard HW (Ed). Modern methods in orchid conservation: the role of physiology, ecology and management. Cambridge:University Press. p. 73-85. 
KERBAUY G; HANDRO W. 1981. Estudo do desenvolvimento in vitro de embriões de orquídeas. In: Huber G. (Ed). Anais do I Encontro Nacional de Orquidólogos. Rio de Janeiro: Expressão e Cultura. p. 147-152.

KNUDSON L. 1922. Non-symbiotic germination of orchid seed. Bot. Gaz. 73: 1-25.

KNUDSON L. 1946. A new nutrient solution for germination of orchid seed. American Orchid Society Bulletin 15: 214-217.

MILANEZE MA. 1997. Estudos em orquídeas nativas do Brasil: Morfologia de sementes e cultivo assimbiótico. Rio Claro: UNESP. (Tese doutorado).

ODDIE RLA; DIXON KW; MCCOMB JA. 1994. Influence of substrate on asymbiotic and symbiotic in vitro germination and seedling growth of two Australian terrestrial orchids. Lindleyana 9: 183-189.

PIERIK RLM. 1990. Cultivo in vitro de plantas superiores. Madrid: Premia de Mar. 325p.
PRITCHARD HW; SEATON PT. 1993. Orchids seed storage: Historical perspective current status and future prospects for long-term conservation. Selbyana 14: 89-104.

RASMUSSEN HN; ANDERSENTF; JOHANSEN TFB. 1990. Temperature sensitive of in vitro germination and seedling development of Dactylorhiza majalis (Orchidaceae) with and without a mycorrhizae fungus. Plant and Cell Environment 13: 171-177.

SEATON PT; HAILES NSJ. 1989. Effect of temperature and moisture content on viability of Cattleya aurantiaca seed. In: Pritchard HW.(Ed). Modern methods in orchid conservation: the role of physiology, ecology and management. Cambridge: University Press. p. 17-29.

SINGH F. 1981. Differential staining of orchid seeds for viability testing. American Orchid Society Bulletin 50: 416 -418.

SINGH F. 1988. Storage of orchid seeds in organic solvents. Gartenbauwissenschaft 53: 122-124.
SNOW R. 1985. Improvements in methods for germination of orchid seeds. American Orchid Society Bulletin 54: 178-181.

THOMPSON PA. 1980. Orchids from seed: Royal Botanic garden Kew. London: Mc Corquodale Printers Ltd. 29p.

VAN DER KINDEREN, G. 1987. Abscisic acid in terrestrial orchid seed: a possible impact on their germination. Lindleyana 2: 84-87.

VAN WAES JM; DEBERGH PC. 1986. Adaptation of the tetrazolium method for testing the seed viability, and scanning electron microscopy study of some Western European orchids. Physiologia Plantarum 66: 435-442.

VUJANOVIC V; ST-ARNAUD M; BARABÉ D. 2000. Viability testing of orchid seed and the promotion of coloration and germination. Annals of Botany 86: 79-86.

WILSON JK. 1915. Calcium hypochlorite as a seed sterilizer. American Journal of Botany 2: 420-424. 